DOI: https://doi.org/10.15407/techned2020.05.062

\title{
THE IMPACT OF SAMPLING FREQUENCY ON THE ACCURACY OF TRAVELLING WAVE-BASED FAULT PROTECTION METHODS
}

Journal

Publisher

ISSN

Issue

Pages
Tekhnichna elektrodynamika

Institute of Electrodynamics National Academy of Science of Ukraine 1607-7970 (print), 2218-1903 (online)

No 5, 2020 (September/October)

$62-64$

\section{Authors \\ P. Regulski ${ }^{\star}$, D.Bejmert ${ }^{\star *}$ \\ Wroclaw University of Science and Technology, \\ Wyb. Wyspianskiego 27, 50-370 Wroclaw, Poland, \\ e-mail: pawel.regulski@pwr.edu.pl \\ * ORCID ID : https://orcid.org/0000-0002-6076-2627 \\ ** ORCID ID : https://orcid.org/0000-0001-6525-0199}

\begin{abstract}
This paper investigates the impact of sampling frequency on the effectiveness of travelling wave-based fault detection and location in cases when the fault is very close to the relay location. The arrival times of consecutive reflected travelling waves in such situations may result in errors if the sampling frequency of the relay is too low. Effectively, this will limit the accuracy of estimated fault location. This issue is investigated by simulating a fault close to the relay and observing the extracted voltage travelling waves for different sampling frequencies. The results confirm a strong correlation and prove that high accuracy will require higher sampling frequencies. References 7 , figures 4.
\end{abstract}

Key words: Travelling wave, line protection, fault location, sampling frequency.

Received: 28.02.2020 
Accepted: 01.06 .2020

Published: 25.08.2020

\section{References}

1. SEL 401L Ultra-High-Speed Line Relay, Schweitzer Engineering Laboratories, Pullman, USA. URL: https://selinc.com/products/T401L/ (accessed 15.12.2019)

2. Chamia M., Liberman S. Ultra High Speed Relay for EHV/UHV Transmission Lines --

Development, Design and Application. IEEE Transactions on Power Apparatus and Systems.

1978. Vol. PAS-97. No 6. Pp. 2104-2116.

DOI:

https://doi.org/10.1109/TPAS.1978.354714

3. Schweitzer E. O., Kasztenny B., Guzmán A., Skendzic V., Mynam M.V. Speed of Line Protection - Can We Break Free of Phasor Limitations? Locating Faults and Protecting Lines at the Speed of Light: Time-Domain Principles Applied, 2018. $14 \mathrm{p}$.

4. Spoor D., Jian Guo Zhu. Improved single-ended traveling-wave fault-location algorithm based on experience with conventional substation transducers. IEEE Transactions on Power Delivery. 2006. Vol. 21. No 3. Pp. 1714-1720.

DOI:

https://doi.org/10.1109/TPWRD.2006.878091

5. Naidu O., Pradhan A.K. A Traveling Wave-Based Fault Location Method Using Unsynchronized Current Measurements. IEEE Transactions on Power Delivery. 2019. Vol. 34. No 2. Pp. 505-513.

DOI:

https://doi.org/10.1109/TPWRD.2018.2875598

6. Shi S., Zhu B., Lei A., Dong X. Fault Location for Radial Distribution Network via Topology and Reclosure-Generating Traveling Waves. IEEE Transactions on Smart Grid. 2019. Vol. 10. No 6. Pp. 6404-6413.

DOI:

https://doi.org/10.1109/TSG.2019.2904210

7. Zhang C., Song G., Wang T., Yang L. Single-Ended Traveling Wave Fault Loca-tion Method in DC Transmission Line Based on Wave Front Information. IEEE Transactions on Power Delivery . 2019. Vol. 34. No 5. Pp. 2028-2038.

DOI: https://d

oi.org/10.1109/TPWRD.2019.2922654 
PDF

@ $\Theta \Theta \Theta$

This work is licensed under a Creative Commons Attribution-NonCommercial-NoDerivatives 4.0 International License 